\title{
Ursolic acid inhibits proliferation and reverses drug resistance of ovarian cancer stem cells by downregulating ABCG2 through suppressing the expression of hypoxia-inducible factor-1 $\alpha$ in vitro
}

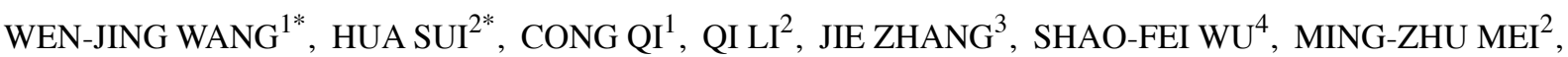 \\ YING-YU LU ${ }^{1}$, YI-TING WAN ${ }^{1}$, HANNAH CHANG $^{1}$ and PIAO-TING GUO ${ }^{5}$ \\ Departments of ${ }^{1}$ Gynecology, ${ }^{2}$ Medical Oncology, Shuguang Hospital, Shanghai University \\ of Traditional Chinese Medicine, Shanghai 201203; ${ }^{3}$ Department of Science and Technology, \\ Longhua Hospital Affiliated to Shanghai University of Traditional Chinese Medicine, Shanghai 200032; \\ ${ }^{4}$ Department of Hepatopathy, Shandong Provincial Qianfoshan Hospital, Shandong University, Jinan, \\ Shandong 250014; ${ }^{5}$ Department of Medical Oncology, Shanghai General Hospital, Shanghai 201203, P.R. China
}

Received January 6, 2016; Accepted February 14, 2016

DOI: $10.3892 /$ or.2016.4813

\begin{abstract}
Hypoxia in tumors is closely related to drug resistance. It has not been verified whether hypoxia-inducible factor- $1 \alpha(\mathrm{HIF}-1 \alpha)$ or ABCG2 is related to hypoxia-induced resistance. Ursolic acid (UA), when used in combination with cisplatin can significantly increase the sensitivity of ovarian cancer stem cells (CSCs) to cisplatin, but the exact mechanism is unknown. The cell growth inhibitory rate of cisplatin under different conditions was evaluated using Cell Counting Kit-8 (CCK-8) in adherence and sphere cells (SKOV3, A2780, and HEY). The expression of HIF-1 $\alpha$ and ABCG2 was tested using quantitative PCR, western blotting, and immunofluorescence under different culture conditions and treated with UA. Knockdown of HIF-1 $\alpha$ by shRNA and LY294002 was used to inhibit the activity of PI3K/Akt pathway. Ovarian CSCs express stemness-related genes and drug resistance significantly higher than normal adherent cells. Under hypoxic conditions, the ovarian CSCs grew faster and were more drug resistant than under normoxia. UA could inhibit proliferation and reverse the drug resistance of ovarian CSC by suppressing ABCG2 and
\end{abstract}

Correspondence to: Dr Cong Qi, Department of Gynecology, Shuguang Hospital, Shanghai University of Traditional Chinese Medicine, Shanghai 201203, P.R. China

E-mail: qicongxzq@aliyun.com

Dr Qi Li, Department of Medical Oncology, Shuguang Hospital, Shanghai University of Traditional Chinese Medicine, Shanghai 201203, P.R. China

E-mail: lzwf@hotmail.com

*Contributed equally

Key words: ursolic acid, ovarian cancer stem cells, ABCG2, drug resistant, HIF-1 $\alpha$
HIF-1 $\alpha$ under different culture conditions. HIF-1 $\alpha$ inhibitor YC-1 combined with UA suppressed the stemness genes and ABCG2 under hypoxic condition. The PI3K/Akt signaling pathway activation plays an important functional role in UA-induced downregulation of HIF- $1 \alpha$ and reduction of ABCG2. UA inhibits the proliferation and reversal of drug resistance in ovarian CSCs by suppressing the expression of downregulation of HIF-1 $\alpha$ and ABCG2.

\section{Introduction}

Ovarian cancer is the fifth common cause of cancer-related deaths in women, and the rate of mortality is the highest in all the gynecologic malignancies. The high rates of mortality in women with ovarian cancer are due to its late diagnosis, with approximately three-fourths of patients diagnosed with advanced disease (1). Although in recent years, with the advances in chemotherapy, the treatment for ovarian cancer has shown significant improvement with consequent reduction in the rate of mortality, the treatment is susceptible to chemotherapeutic drug resistance, in particular the emergence of multidrug resistance (MDR). The 5-year rate of survival of patients with ovarian cancer is only $27 \%$ (2).

A very few subgroups of tumor cells have the ability to self-renew, differentiate, and form secondary/tertiary tumors after serial xenotransplantation into immune-compromised animal models and are called cancer stem cells (CSCs) or cancer-initiating cells (3). With the development of CSCs, ovarian CSCs have been isolated from ovarian solid tumors, ovarian cell lines, and ovarian cancer ascites (4). Increasing number of studies have demonstrated that CSCs are closely associated with drug resistance. ATP-binding cassette (ABC), subfamily $G$, member 2 (ABCG2), is highly expressed in various stem cell populations, and has become one of the stem cell markers $(5,6)$. Furthermore, ABCG2 is an important MDR transporter, which can efflux various chemotherapeutic drugs and may contribute to drug resistance of cancer cells (7-10). 
Current evidence suggests that ABCG2 gene transcription is regulated by a number of trans-acting elements including hypoxia-inducible factor $1 \alpha(\mathrm{HIF}-1 \alpha)$, estrogen receptor, and peroxisome proliferator-activated receptor. Among these, HIF-1 $\alpha$, a master transcription factor that regulates hypoxiaresponsive genes, has been recognized to play a critical role in tumor, metastasis, and chemoradiation resistance (11-15).

Ursolic acid (UA; 3 $\beta$-hydroxy-urs-12-en-28-oic acid) is a naturally-derived pentacyclic triterpene acid widely present in medicinal and other plants (16). UA has a number of biological properties including antioxidation, anti-inflammation, anticancer, and hepatoprotection (17-19). However, the exact mechanism through which the anticancer and reversal of multidrug resistant properties occurs remains unclear. Therefore, major improvements are required in the development of safe and effective method for the reversal of multidrug resistance.

\section{Materials and methods}

Cells and cell culture. Ovarian cancer cell line SKOV3 was obtained from the International Peace Maternity and Child Health Hospital (Shanghai, China). This cell line had been used in our previous study which was cooperating with International Peace Maternity and Child Health Hospital and approved by the Ethics Committee of the International Peace Maternity and Child Health Hospital (20). The HEY and A2780 cells were purchased from the Shanghai Cell Collection (Shanghai, China) (http://www.cellbank.org.cn). All cells were maintained in RPMI-1640 (Hyclone, Logan, UT, USA), supplemented with $10 \%$ fetal bovine serum (FBS) (Gibco, Grand Island, NY, USA) at $37^{\circ} \mathrm{C}$.

Ovarian cancer sphere culture: Single cancer cells wereplated in the cell culture dish $(100 \times 200 \mathrm{~mm}$ style; Corning, NY, USA), which had been treated with poly-(2-hydroxyethyl methacrylate (poly-HEMA) (Sigma, St. Louis, MO, USA), for continuous suspension culture. The cells were maintained in embryonic stem (ES) medium (serum-free Dulbecco's modified Eagle's medium-F12; Hyclone), supplemented with $10 \mathrm{ng} / \mathrm{ml}$ basic fibroblast growth factor (bFGF; Gibco), $5 \mu \mathrm{g} / \mathrm{ml}$ insulin (Sigma), $1 \mathrm{mM}$ L-glutamine (Sigma), 10\% knockout serum replacement and penicillin/streptomycin $(1000 \mathrm{U} / \mathrm{ml}$ and $100 \mathrm{mg} / \mathrm{ml}$; Invitrogen, Carlsbad, CA, USA) (21). Stem cells grown under these conditions formed non-adherent spherical clusters. To induce the hypoxic environment, the HERA cell $\mathrm{CO}_{2}$ incubator (Thermo, Germany) was chosen and maintained with $1 \% \mathrm{O}_{2}, 5 \% \mathrm{CO}_{2}$, and $94 \% \mathrm{~N}_{2}$.

Quantitative PCR. Total RNAs were extracted using the RNeasy extraction kit (Qiagen, Zürich, Switzerland). After reverse transcription of RNA to cDNA, quantitative polymerase chain reaction ( $\mathrm{qPCR}$ ) using the converted cDNA as template was performed in triplicate using SYBR Green PCR Master Mix. PCR was performed using initial denaturation at $95^{\circ} \mathrm{C}$ for $2 \mathrm{~min}$, followed by 40 cycles for $10 \mathrm{sec}$ at $95^{\circ} \mathrm{C}$ and $30 \mathrm{sec}$ at $60^{\circ} \mathrm{C}$. The threshold cycle (CT) values of each sample were used in the post-PCR data analysis. Glyceraldehyde 3-phosphate dehydrogenase (GAPDH) was used as an internal control for mRNA-level normalization. The following primers were used: CD44 F: ACCCCATCCCAGACGAAGACAGTC,
R: GGGATGAAGGTCCTGCTTTCCG; NANOG F: GCA AAAAAGGAAGACAAGGTCC, R: CCTTCTGCGTCA CACCATTG; OCT-4 F: CGAAGAGAAAGCGAACCAGT ATC, R: AGAACCACACTGGACCACATC; ABCG2 F: GGT TTCCAAGCGTTCATTCAAA, R: TAGCCCAAAGTAAAT GGCACCTA; HIF-1 $\alpha$ F: CCACAGGACAGTACAGGATG, R: TCAAGTCGTGCTGAATAATACC; GAPDH: F: GGT GGTCTCCTCTGACTTCAACA, R: CCAAATTCGTTGT CATACCAGGAAATG.

Cell viability assay. For cell viability assay using Cell Counting Kit-8 (CCK-8), cells were seeded onto 96-well plates at $1 \times 10^{5}$ cells/well and the medium was treated with the drug (cisplatin-DDP, UA) for $48 \mathrm{~h}$. After $2 \mathrm{~h}$ of incubation with culture medium containing the CCK- 8 reagent (Tongji, Tokyo, Japan), the absorbance was read at $450 \mathrm{~nm}$ using a microplate enzyme-linked immunosorbent assay reader.

Apoptosis assay using Annexin V staining. Apoptotic cells were quantified using an Annexin V-APC/7-aminoactinomycin D (7-AAD) kit (Becton, Dickinson and Co., San Jose, CA, USA) and detected using flow cytometry according to the manufacturer's protocol. After treatment with UA and/or DDP, respectively, cells were resuspended in $100 \mu 11 \mathrm{X}$ binding buffer and incubated with $5 \mu \mathrm{l}$ Annexin V-APC and $5 \mu \mathrm{l}$ 7-AAD for $15 \mathrm{~min}$ in the dark. After staining, $400 \mu \mathrm{l}$ of $1 \mathrm{x}$ binding buffer was added to the cells, and samples were analyzed using flow cytometry. Cells in the early stage of apoptosis stained onlypositive for Annexin $\mathrm{V}$, while those in the late stage stained positive for both Annexin V and 7-AAD.

Western blots. Whole-cell lysate for sodium dodecyl sulfatepolyacrylamide gel electrophoresis, and cells were washed twice with phosphate-buffered saline containing protease inhibitors. The protein content was determined using the bicinchoninic acid protein assay using a commercial kit (BSA Protein Assay Reagent; Merck \& Co., White House Station, NJ, USA). The following antibodies were used: rabbit anti-CD44 antibody, rabbit anti-Nanog antibody, mouse anti-OCT-4 antibody, rabbit anti-p-AKT-308 antibody, rabbit anti-p-AKT-492 antibody, rabbit-AKT antibody, rabbitPI3K antibody (all Cell Signaling Technology, Beverly, MA, USA), mouse anti-HIF-1 $\alpha$ antibody (Novus Biologicals LLC, Littleton, CO, USA), rabbit anti-ABCG2 antibody, rabbit-antiP-gp antibody (all Abcam, Cambridge, MA, USA). Equal loading was confirmed using GAPDH. Densitometric analysis was performed using the Scion Imaging software (Scion Corp., Tokyo, Japan), using GAPDH as a control for each sample.

Immunofluorescence staining. Cells were seeded onto glass slides and fixed with $4 \%$ paraformaldehyde, permeabilized with Triton X-100, and subsequently incubated with the monoclonal mouse anti-ABCG2 antibody and mouse antiHIF-1 $\alpha(1: 50)$ overnight at $4^{\circ} \mathrm{C}$. Samples were incubated with goat anti-mouse immunoglobulin $\mathrm{G}$ antibody (Biyuntian Biological, Nanjing, China), and cell nuclei were stained with 4',6-diamidino-2-phenylindole (DAPI; Biyuntian Biological). Images were captured using a $80 \mathrm{i}$ laser confocal microscope (Nikon, Tokyo, Japan). Images were further digitally processed for contrast enhancement using Adobe Photoshop. 
A
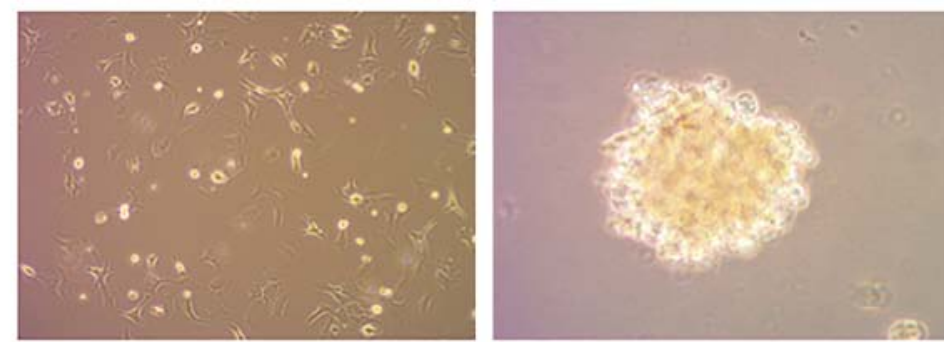

SKOV3-ad

SKOV3-sp

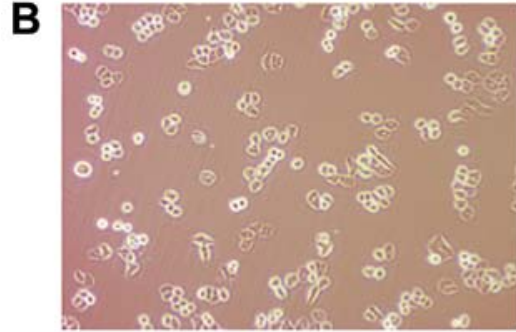

A2780-ad

C

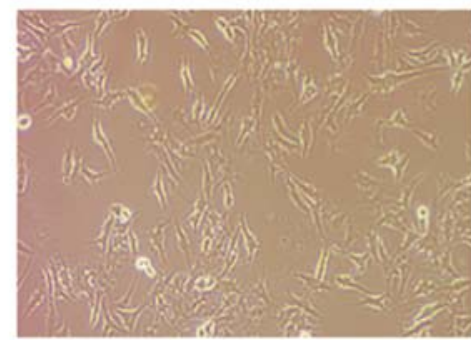

HEY-ad

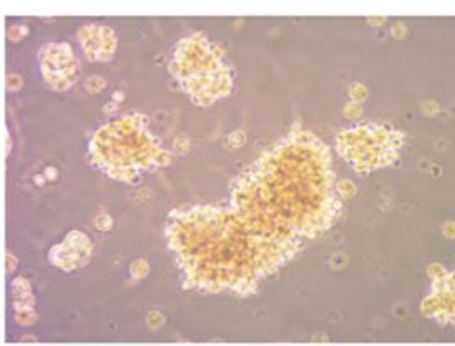

A2780-sp

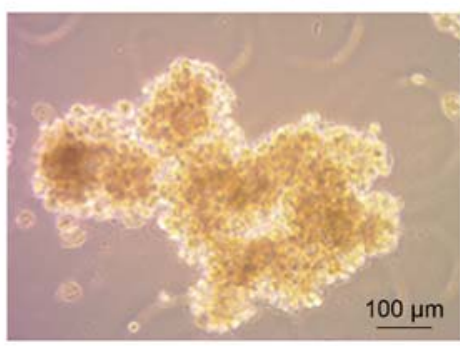

HEY-sp

Figure 1. The morphology of tumor spheres. (A) SKOV3 cells were maintained in RPMI-1640 with 10\% FBS (SKOV3-ad, SKOV3-adherence) and in ES medium (SKOV3-sp, SKOV3-spheres). (B) A2780 cells were maintained in RPMI-1640 with 10\% FBS (A2780-ad, A2780-adherence) and in ES medium (A2780-sp, A2780-spheres) (100e). (C) HEY cells were maintained in RPMI-1640 with 10\% FBS (HEY-ad, HEY-adherence) and in ES medium (HEY-sp, HEY-spheres). Scale bars represent $100 \mu \mathrm{M}$.

Plasmid DNA amplification, extraction, and purification. The plasmids were transformed into DH5a competent cells, extracted, and purified according to the plasmid extraction kit instructions (Tiangen, Beijing, China). The concentration of the obtained plasmid DNA was measured using spectrophotometry, and the absorbance of the plasmid was measured at $260 \mathrm{~nm}$. The $\mathrm{OD}_{260}$ titration was between 1.8 and 2.1, indicating that there was no contamination in the plasmid DNA.

Plasmid transfection. Cell culture plate was prepared using $40 \%$ cell density and $30 \mu \mathrm{l}$ serum-free RPMI-1640 was added to a plastic tube. Plasmid DNA $(1 \mu \mathrm{g})$ was added to the tube and mixed by pipetting. HilyMax was added to prepare DNA $(\mu \mathrm{g})$ : HilyMax $(\mu \mathrm{l})=1: 3$ and mixed by pipetting, and the tube was incubated at room temperature for $15 \mathrm{~min}$. DNA-HilyMax complex was added to the cell culture well. The plate was incubated at $37^{\circ} \mathrm{C}$ in a $\mathrm{CO}_{2}$ incubator for $4 \mathrm{~h}$. Later the medium was changed and incubation was continued for $48 \mathrm{~h}$.

Statistical analysis. All data are represented as mean \pm standard deviation. Statistical differences between two datasets were compared using Student's t-test; nonparametric data were compared using the Mann-Whitney U test. SPSS Statistics 21 was used for the statistical analysis.

\section{Results}

Ovarian CSC sphere culture. Ovarian CSC sphere culture and single cancer cells (including SKOV3, A2780, HEY), which have been found to have stemness characteristics when serum-free suspension culture (21-23) when plated onto the cell culture dish, were maintained in ES medium. Stem cells grown under these conditions formed nonadherent spherical clusters. The formation of sphere cells could be observed on the third day and the sphere cells matured on the seventh day (Fig. 1).

Ovarian CSCs express stemness-related genes and drug resistance significantly higher than normal adherent cells. Ovarian cancer cells were maintained in RPMI-1640 with $10 \%$ FBS and ES medium, and the expression of stemnessrelated genes (CD44, CD133, Nanog, Oct-4, and ABCG2) was detected (24-30). The qPCR showed that the expression of CD44, CD133, Nanog, Oct-4, and ABCG2 in stem cell phenotype of SKOV3 sphere cells was much higher than those in the SKOV cells (Fig. 2A). The expression levels of these stemness genes in HEY and A2780 sphere cells were much higher than in the normal adherent cells (Fig. 2A-C). To investigate whether ovarian CSCs have significantly higher drug resistance than normal adherent cells, different concentrations of cisplatin (Sigma) were used to treat cells, and after $48 \mathrm{~h}$ half 

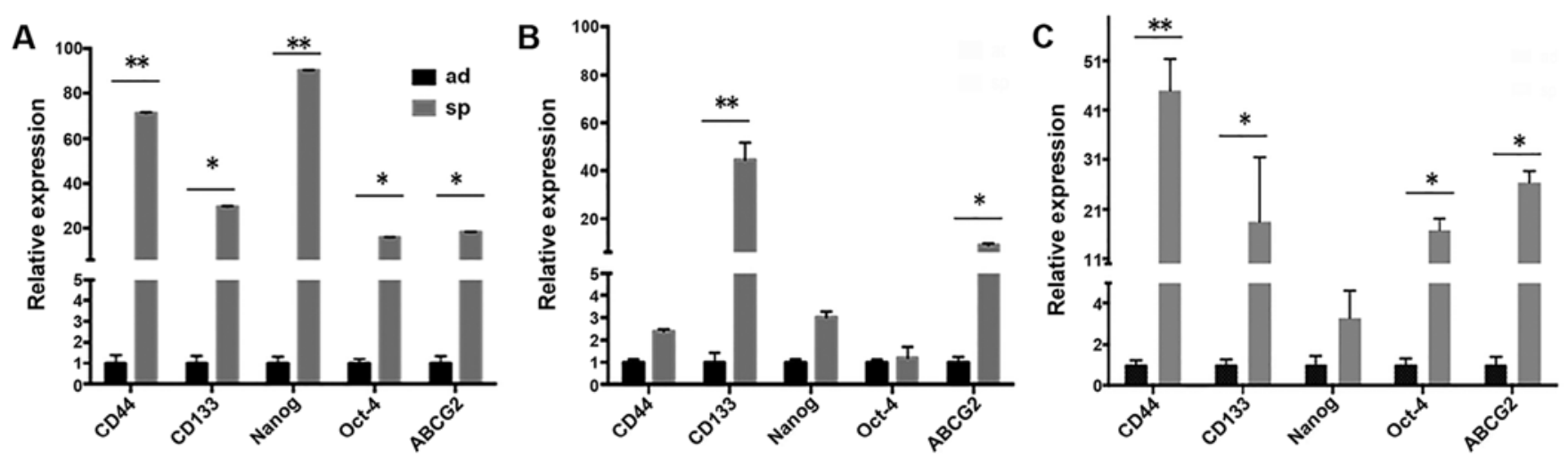

D
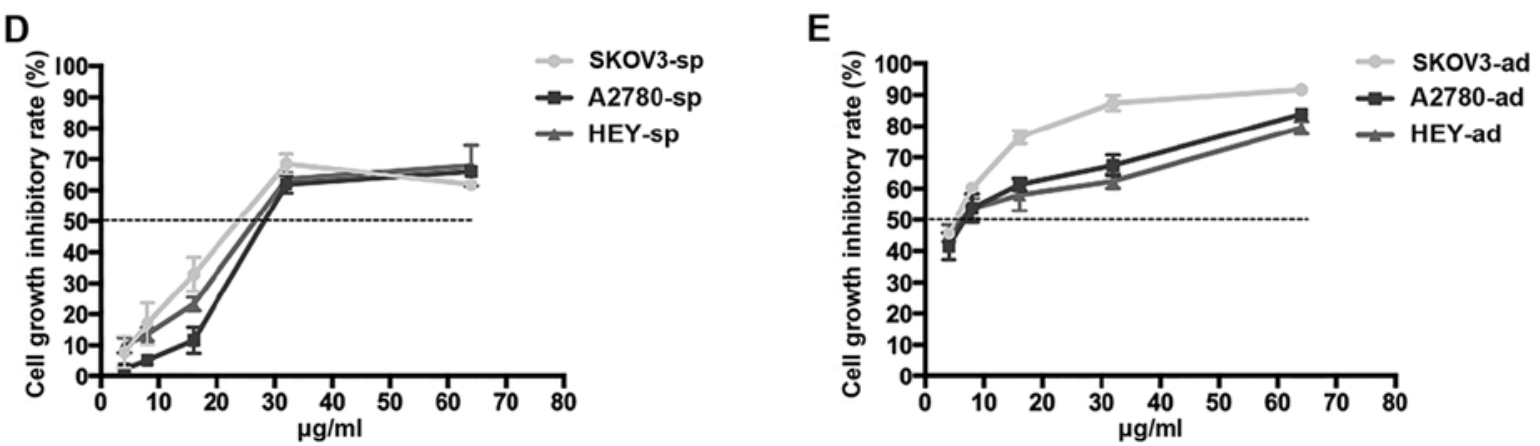

Figure 2. Ovarian cells have characteristics of stem cells. (A-C) Quantitative PCR shows that under stem cell-selective conditions, SKOV3-sp, HEY-sp, and A2780-sp cells overexpressed stemness genes CD44, CD133, Nanog, Oct-4, and ABCG2 compared with SKOV3-ad $\left({ }^{*} \mathrm{P}<0.05\right.$, $\left.{ }^{* *} \mathrm{P}<0.01\right)$. (D) The sphere cells showed stronger drug resistance as compared with the adherence cells after treatment with DDP $(0,4,8,16$, and $32 \mu \mathrm{g} / \mathrm{ml})$. (E) The cell growth inhibitory rate of SKOV3-ad, A2780-ad and HEY-ad with DDP $(0,4,8,16$, and $32 \mu \mathrm{g} / \mathrm{ml})$.

A

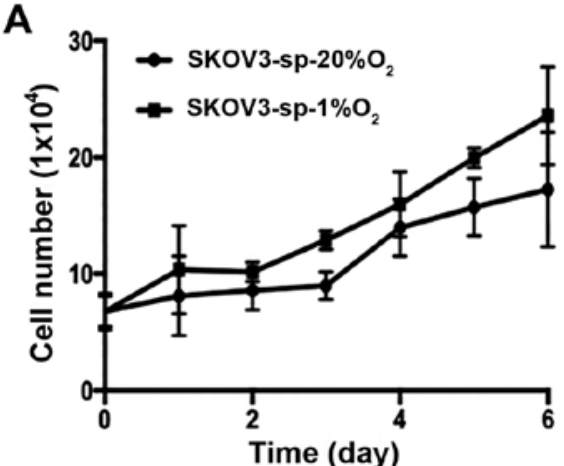

C

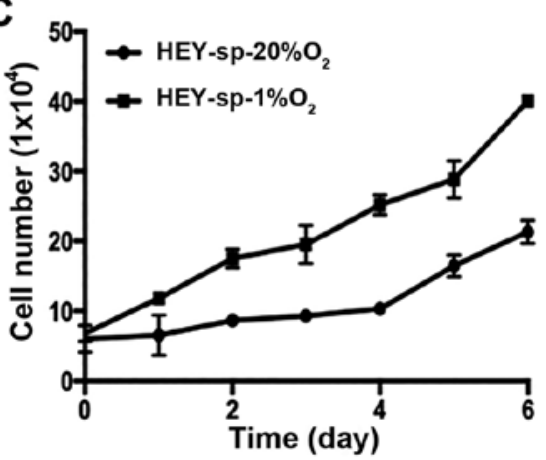

B

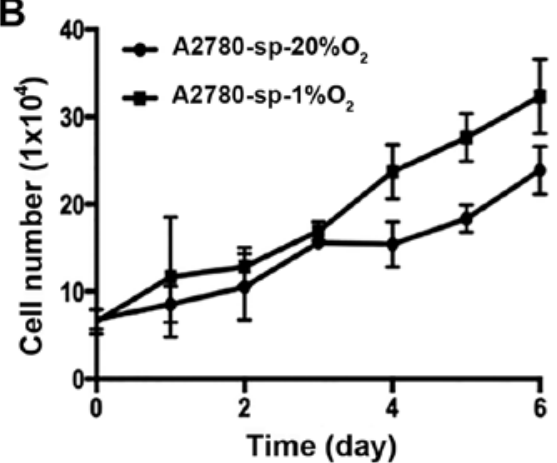

D

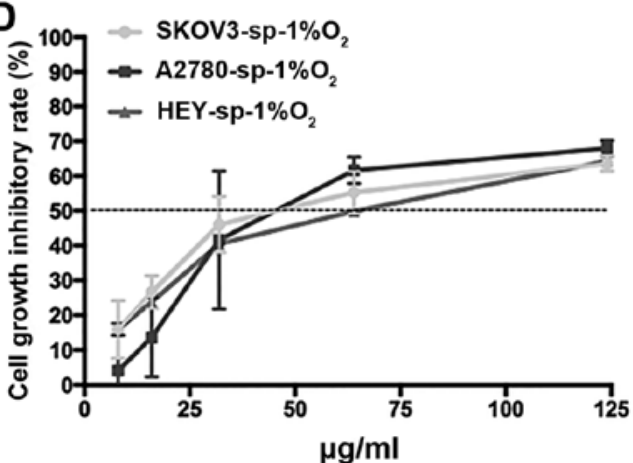

Figure 3. Cell number of ovarian sphere cells under different conditions. (A-C) SKOV3-sp, A2780-sp, and HEY-sp cells under hypoxic conditions grew faster as compared with under normoxia. (D) The $\mathrm{IC}_{50}$ of SKOV3-sp, A2780-sp, and HEY-sp increased significantly under hypoxic conditions when treated with DDP $(4,8,16,32$, and $64 \mu \mathrm{g} / \mathrm{mL})$. $\mathrm{IC}_{50}$, half maximal inhibitory concentration.

maximal inhibitory concentration $\left(\mathrm{IC}_{50}\right)$ of DDP was analyzed using CCK-8. As shown in Fig. 2D, the median $\mathrm{IC}_{50}$ values of SKOV3-sp, A2780-sp, and HEY-sp were 28.223, 35.414, and $30.031 \mu \mathrm{g} / \mathrm{ml}$, respectively. The $\mathrm{IC}_{50}$ values of SKOV3-ad, 

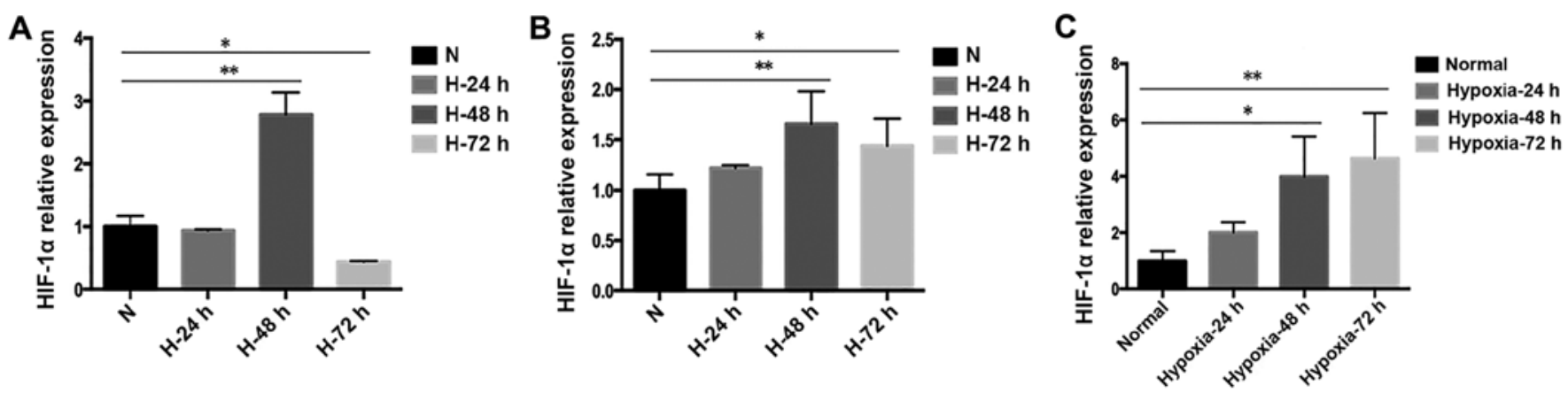

Figure 4. Expression of HIF-1 $\alpha$ at different time points. (A) SKOV3-sp cultured under normal $\left(20 \% \mathrm{O}_{2}\right.$, N) and hypoxic conditions for $24 \mathrm{~h}$ (H-24 h), $48 \mathrm{~h}$ (H-48 h), and $72 \mathrm{~h}$ (H-72 h). (B) HEY-sp cultured under N and H-24 h, H-48 h, and H-72 h. (C) A2780-sp cultured under N and H-24 h, H-48 h, and H-72 h. The experiment was repeated thrice $\left({ }^{*} \mathrm{P}<0.05,{ }^{* *} \mathrm{P}<0.01\right)$.

A

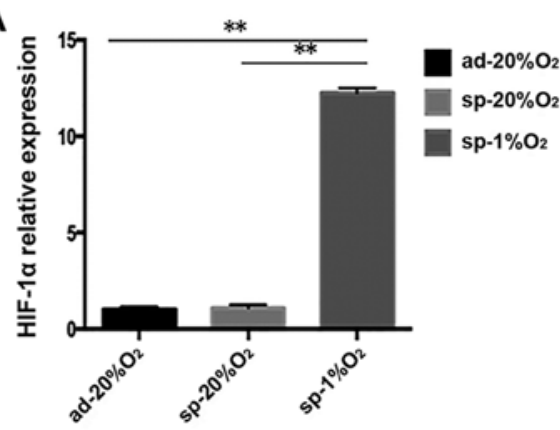

B

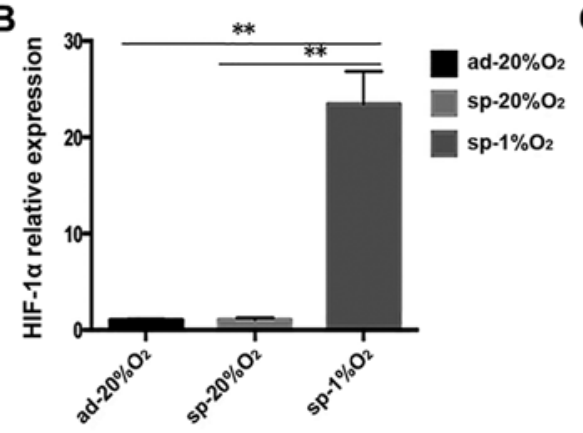

C

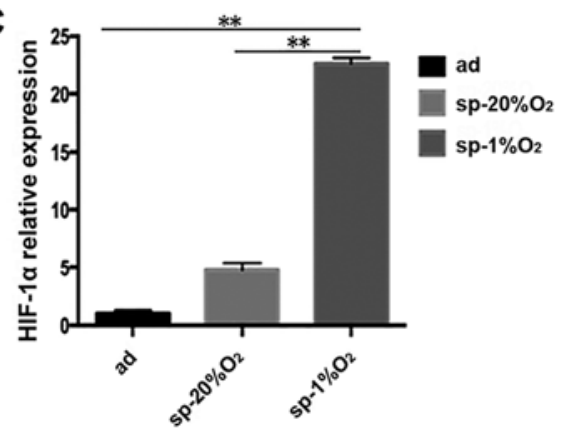

Figure 5. Expression of HIF-1 $\alpha$ after 48 h hypoxia culturing (A) SKOV3-ad and SKOV3-sp were cultured under normal conditions. At the same time, SKOV3-sp was cultured under normoxic and hypoxic conditions for 48 h. (B) HEY-ad and HEY-sp were cultured under normal conditions. At the same time HEY-sp was cultured under normoxic and hypoxic conditions for $48 \mathrm{~h}$. (C) A2780-ad and A2780-sp were cultured under normal conditions. At the same time, A2780-sp was cultured under normoxic and hypoxic conditions for $48 \mathrm{~h}$. The experiment was repeated thrice $\left({ }^{*} \mathrm{P}<0.05,{ }^{* *} \mathrm{P}<0.01\right)$.

A2780-ad, and HEY-ad were 4.910, 7.073, and $6.576 \mu \mathrm{g} / \mathrm{ml}$ (Fig. 2E), respectively.

It was observed that the $\mathrm{IC}_{50}$ of sphere cells is much higher than the normal adherent cells, and sphere cells exhibited higher resistance to chemotherapeutic drugs, with higher rates of survival.

Under hypoxic conditions, ovarian CSCs grow faster and more drug-resistant than under normoxia. The SKOV3-sp, A2780-sp, and HEY-sp cells grown under $20 \%$ or $1 \%$ oxygen at different time points and proliferation were measured by counting the cells (Fig. 3A-C). As shown in Fig. 3A and B, the initial concentrations of SKOV3-sp, A2780-sp, and HEY-sp were $6.7 \times 10^{4}, 6.5 \times 10^{4}$ and $6.0 \times 10^{4}$, respectively, after 7 days of culture under different conditions. The sphere cells grew faster than under normoxia. In this experiment, it can be observed that hypoxia can promote the proliferation of sphere cells. At the same time, under hypoxic condition, the sphere cells developed more drug resistance than under normoxia. The $\mathrm{IC}_{50}$ values of SKOV3-sp, A2780-sp, and HEY-sp were 51.653, 53.889, and $60.774 \mu \mathrm{g} / \mathrm{mL}$, respectively (Fig. 3D). Thus, under hypoxic condition, the $\mathrm{IC}_{50}$ increased significantly.

Under hypoxic conditions, the ovarian CSCs exhibit higher stemness than under normal conditions. Recent advances in cancer research have demonstrated that the enhanced expression and activation of HIFs are frequent in cancer cells during the progression of cancer and is associated with the acquisition of a more malignant behavior, drug resistance, and poor rate of survival in patients with cancer (31-34). Hence the expression of HIF-1 $\alpha$ at different time points was tested (Fig. 4). It was observed that when SKOV3-sp, HEY-sp, and A2780-sp cells were cultured under hypoxic condition $\left(1 \% \mathrm{O}_{2}\right)$ for 24,48 , and $72 \mathrm{~h}$, the expression of HIF-1 in SKOV3 was higher at $48 \mathrm{~h}$ than at 24 or $72 \mathrm{~h}$ (Fig. 4A), and the expression of HIF-1 $\alpha$ in HEY-sp was the same as SKOV3-sp (Fig. 4B). However, in A2780-sp, it was found that after $72 \mathrm{~h}$ hypoxia, the expression of HIF-1 $\alpha$ was higher than at 24 or $48 \mathrm{~h}$ (Fig. 4C). In subsequent experiments, $48 \mathrm{~h}$ was selected as the time point for culture since the expression of HIF was significantly increased in all the three cell strains. When cultured under normal condition, the expression of HIF-1 $\alpha$ did not show difference between adherent and sphere cells. The expression of HIF-1 $\alpha$ in the HEY-sp, and A2780-sp cells after $48 \mathrm{~h}$ under hypoxia was significantly increased and was statistically significant (Fig. 5).

In addition, when the sphere cells were cultured under hypoxic condition for $48 \mathrm{~h}$, in SKOV3-sp cells, the expression of stemness genes CD44, CD133, and Nanog was significantly increased $(\mathrm{P}<0.05)$ and the drug resistance gene was apparently more elevated $(\mathrm{P}<0.01)$ (Fig. 6A). In HEY-sp cells after $48 \mathrm{~h}$ hypoxia culture, the expression of stemness genes Nanog and Oct- 4 and drug resistance gene ABCG2 was significantly increased $(\mathrm{P}<0.01)$ (Fig. 6B). In the $\mathrm{A} 2780$-sp, the expres- 

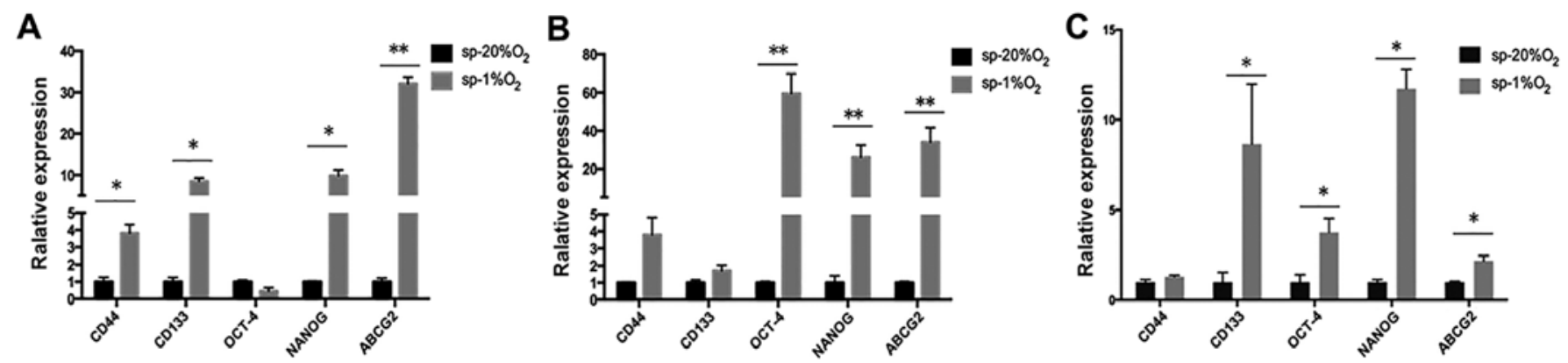

Figure 6. Expression of stemness genes and drug resistance gene under different culture conditions. (A) SKOV3-sp was cultured under normal and hypoxic conditions for $48 \mathrm{~h}$, and then the stemness genes and ABCG2 were tested. (B) After $48 \mathrm{~h}$ of hypoxic culture, the expression of stemness genes and ABCG2 of HEY-sp. (C) After $48 \mathrm{~h}$ of hypoxic culture, the expression of stemness genes and ABCG2 of A2780-sp ( $\left.{ }^{*} \mathrm{P}<0.05,{ }^{* *} \mathrm{P}<0.01\right)$.
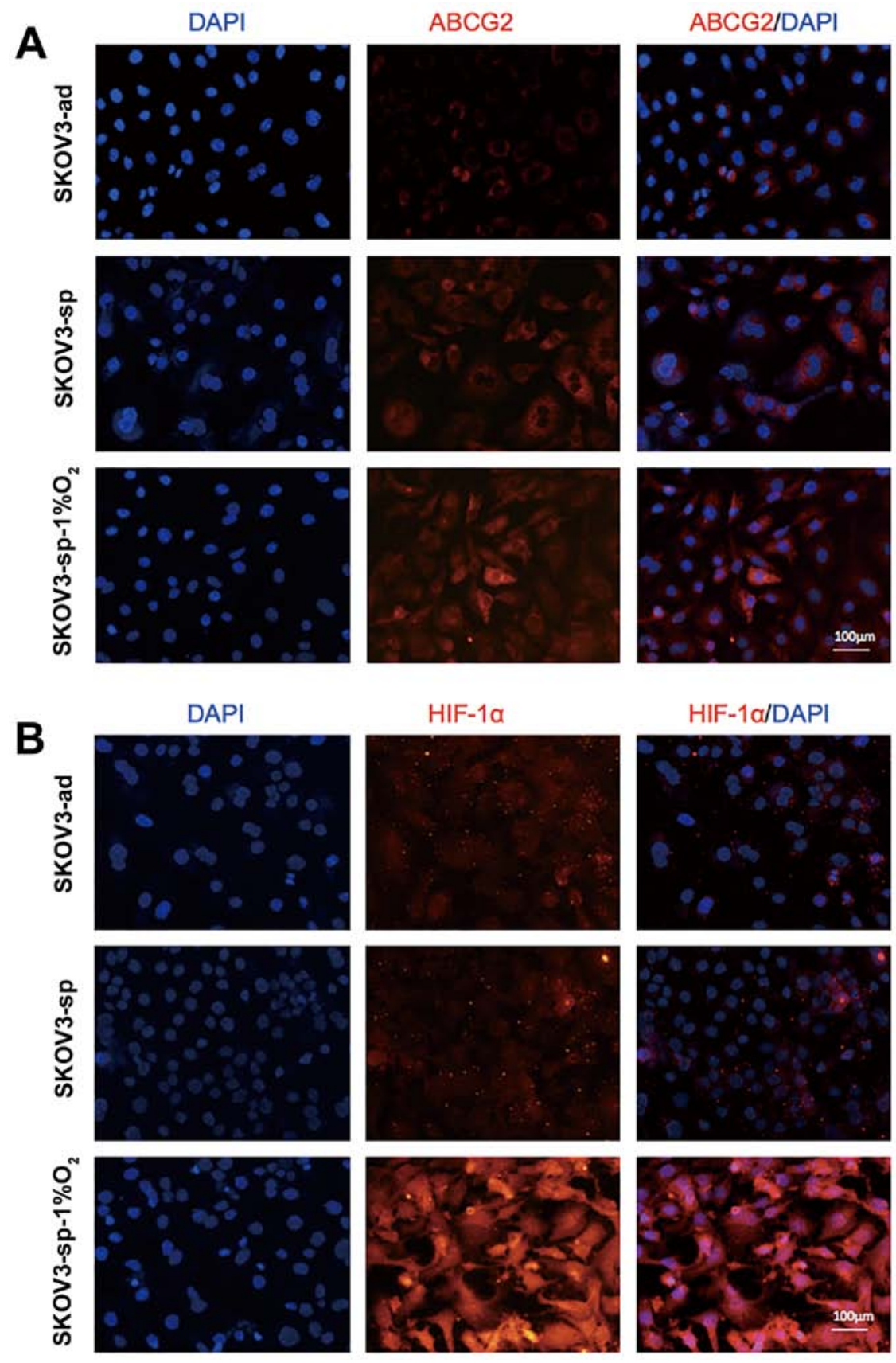

Figure 7. Expression of ABCG2 protein and HIF-1 $\alpha$ protein on SKOV3 under different culture conditions using immunofluorescent assay. (A) The expression of ABCG2 under normal or hypoxic condition. Nuclei were stained with DAPI (in blue) and ABCG2 was stained with CY3 (in red). (B) The expression of HIF-1 $\alpha$ under normal or hypoxic condition. Nuclei were stained with DAPI (in blue) and the HIF-1 $\alpha$ was stained with CY3 (in red). DAPI, 4',6-diamidino2-phenylindole; HIF, hypoxia-inducible factor. 
A

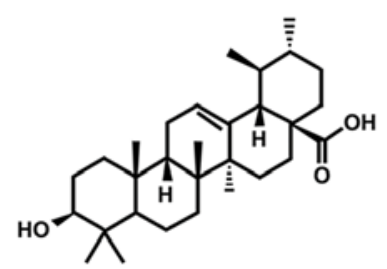

B

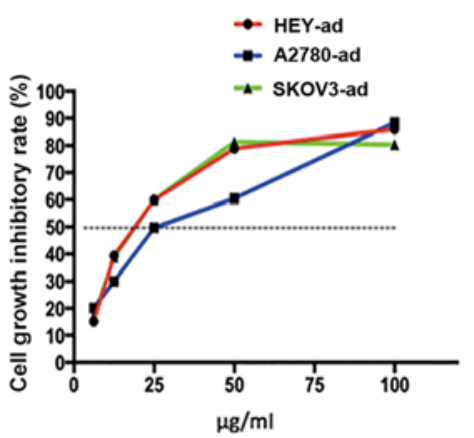

C

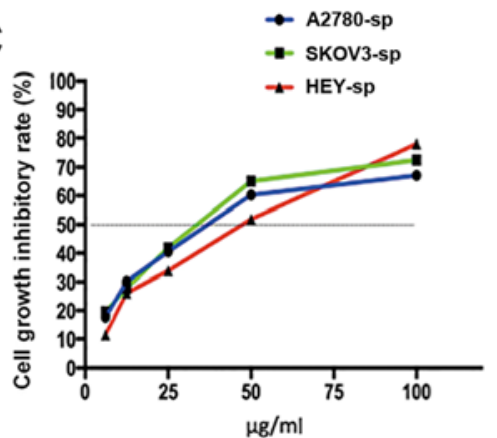

D

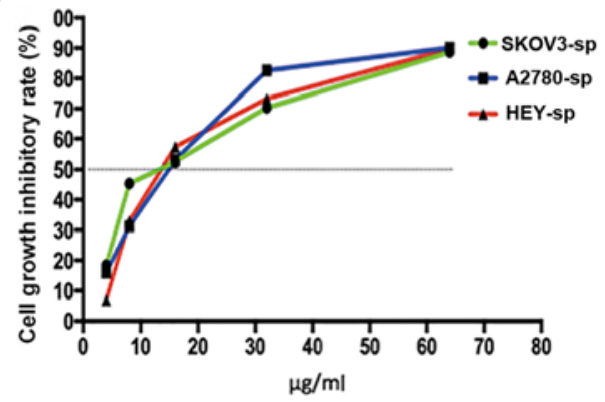

E
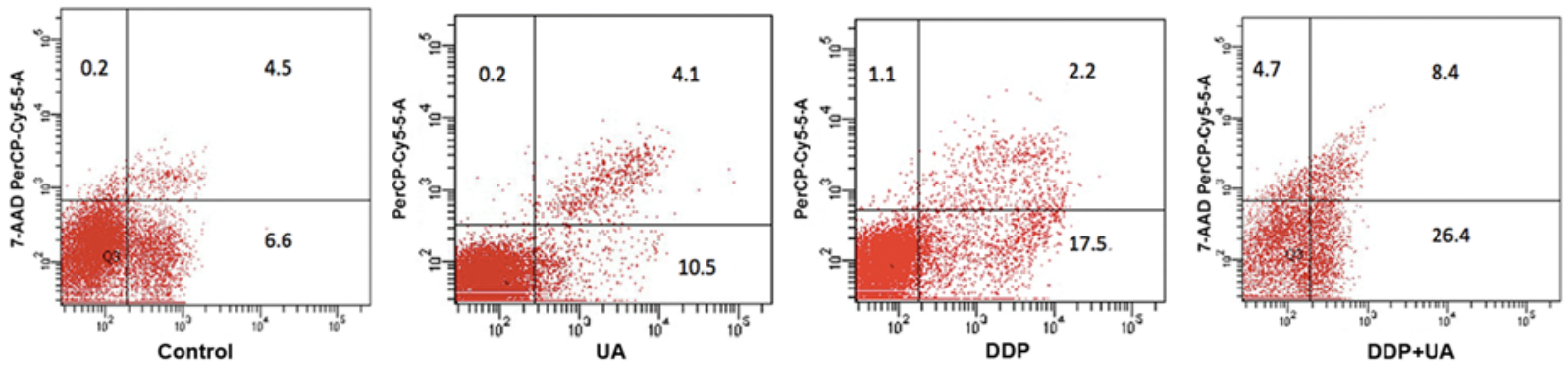

Figure 8. Effects of ursolic acid on proliferation and effect on the sensitivity of cisplatin under hypoxic condition. (A) The chemical structure of ursolic acid. (B) Ursolic acid inhibited the proliferation of SKOV3-ad, HEY-ad, and A2780-ad (6.25, 12.5, 25, 50, and $100 \mu \mathrm{g} / \mathrm{mL}$ ). (C) Ursolic acid inhibited the proliferation of SKOV3-sp, HEY-sp, and A2780-sp $(6.25,12.5,25,50$, and $100 \mu \mathrm{g} / \mathrm{ml})$. (D) The cell growth inhibitory rate when ovarian cells were treated with low-dose ursolic acid $\left(\mathrm{IC}_{10}\right)$ combined with cisplatin $(4,8,16,32$, and $64 \mu \mathrm{g} / \mathrm{mL}$ ). (E) Apoptosis in SKOV3-sp after treatment with ursolic acid and cisplatin for $48 \mathrm{~h}$ under hypoxic condition.

sion of stemness genes CD133, Nanog, and Oct-4 and drug resistance gene ABCG2 was higher than in normal culture $(\mathrm{P}<0.05)$ (Fig. 6C). It was found that after hypoxia culture, with the increase in HIF-1 $\alpha$, the expression of stemness genes and drug gene ABCG2 was elevated.

To further understand the expression of HIF-1 $\alpha$ in ABCG2, the increase in the expression of ABCG2 in SKOV3 cells under hypoxic condition was chosen (Fig. 6), and immunofluorescence staining was performed on SKOV3-ad and SKOV3-sp under different culture conditions. The ABCG2 proteins are mainly found on the plasma membrane (Fig. 7A). It was observed that SKOV3-sp is expressed at higher level than the SKOV3-ad. When SKOV3-sp was cultured under different conditions for $48 \mathrm{~h}$, the sphere cells under hypoxic condition expressed ABCG2 at much higher level than under normal condition (Fig. 7A). At the same time, the expression of HIF-1 $\alpha$ between SKOV3-ad and SKOV3-sp did not show any difference, and when the SKOV3-sp was cultured under hypoxic condition, the expression of HIF-1 $\alpha$ increased significantly (Fig. 7B).

UA inhibits the proliferation and enhances the sensitivity of cisplatin in ovarian CSCs. In this experiment, it was examined whether UA could inhibit the proliferation of ovarian cells and when UA combined with cisplatin can enhance the sensitivity of cisplatin. As shown in Fig. 8B, UA inhibits the adherent and sphere cells. The $\mathrm{IC}_{50}$ values at $48 \mathrm{~h}$ for SKOV3-ad, A2780-ad, and HEY-ad were 19.370, 25.257, and $19.349 \mu \mathrm{g} / \mathrm{ml}$, respectively. The $\mathrm{IC}_{50}$ values of SKOV3-sp, A2780-sp, and HEY-sp were $31.669,36.745$, and $39.239 \mu \mathrm{g} / \mathrm{ml}$, respectively. Among these, the $\mathrm{IC}_{10}$ values of SKOV3-sp, HEY-sp, and A2780-sp were 2.934, 5.359, and $2.557 \mu \mathrm{g} / \mathrm{ml}$ (Fig. 8C). Less than $\mathrm{IC}_{10}$, cell survival was not found to be significantly different from untreated cells. Hence, for cell proliferation experiments, the cells were treated with $\mathrm{UA}$ in the concentration range of $\mathrm{IC}_{10}$.

To investigate the effect of UA on the sensitivity of cisplatin under hypoxic conditions, the $\mathrm{IC}_{10}$ of UA combined with cisplatin for $48 \mathrm{~h}$ was chosen, and then analyzed using CCK-8. It can be observed that the $\mathrm{IC}_{50}$ values of SKOV3-sp, HEY-sp, and A2780-sp were 12.681, 14.759, and $13.302 \mu \mathrm{g} / \mathrm{ml}$. The $\mathrm{IC}_{50}$ values were significantly lower than when cisplatin was used alone (Fig. 8D). It can lead to the increase in the sensitivity of cisplatin due to UA under hypoxic condition.

In addition, the low-dose UA $\left(\mathrm{IC}_{10}\right)$ was chosen for combining with median dose of cisplatin to detect cell apoptosis under hypoxic condition. As shown in Fig. 8D, when low-dose UA was used alone, the rate of apoptosis was $14.6 \%$ and the cell apoptosis did not change. However, compared to treatment with cisplatin alone, combining cisplatin with UA increased the rate of apoptosis from 19.7 to $34.8 \%$ (Fig. 8E). 
A

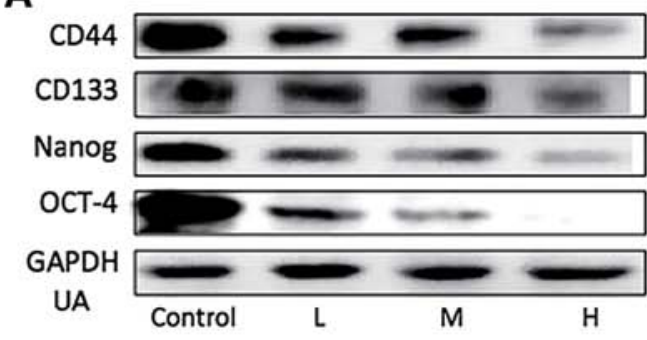

C
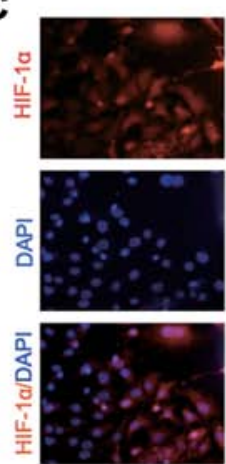
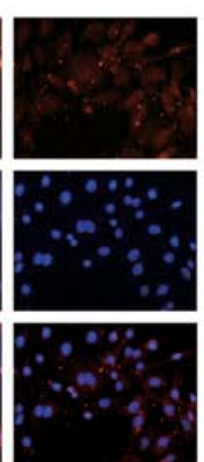
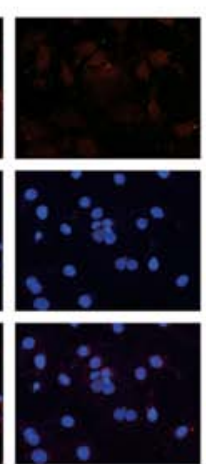

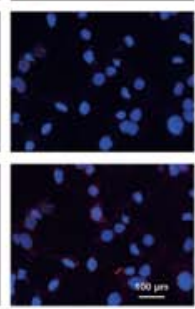

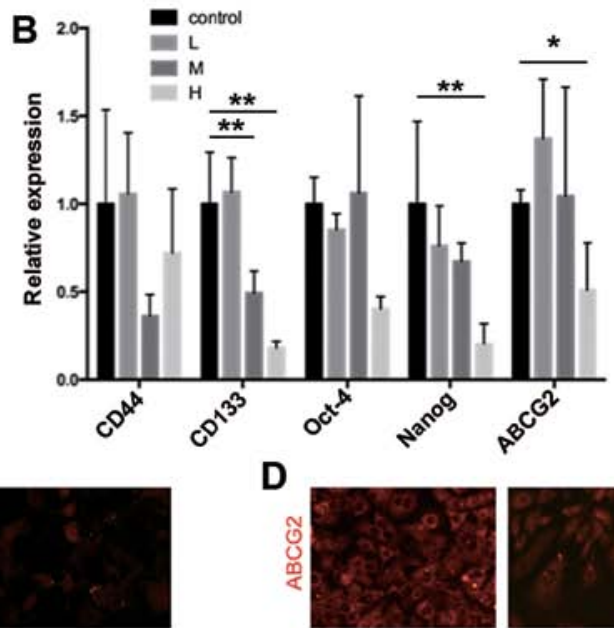

D
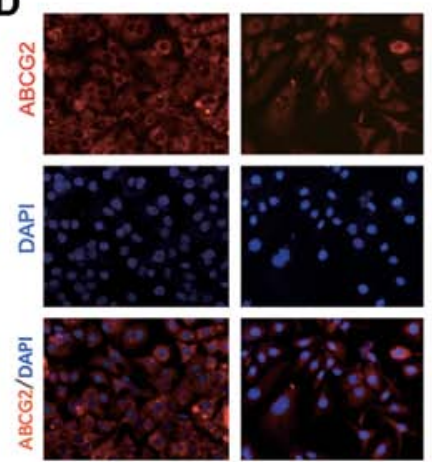
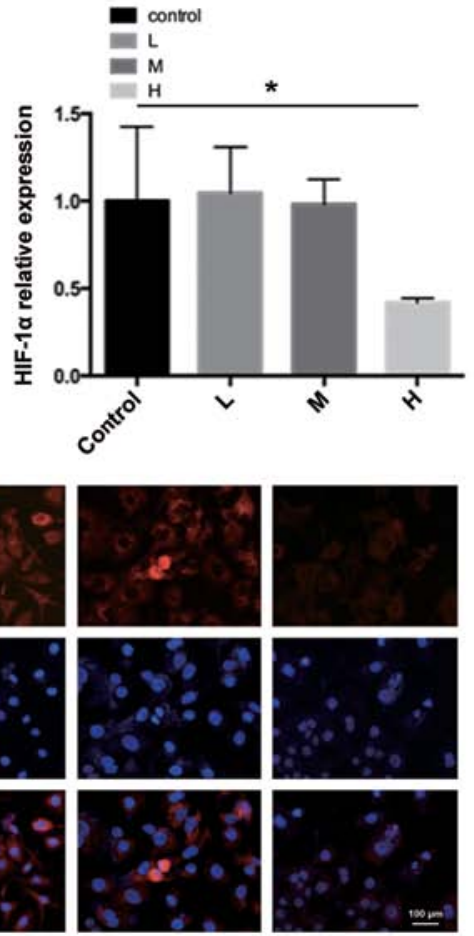

Figure 9. Ursolic acid inhibits ABCG2 and HIF-1 $\alpha$ in SKOV3-sp under hypoxic condition. (A) SKOV3-sp cells were treated with different concentrations of ursolic acid $(3,10$, and $30 \mu \mathrm{g} / \mathrm{mL}$ ) for $48 \mathrm{~h}$ and CD44, CD133, Nanog, and OCT-4 were detected using western blot analysis. (B) Under hypoxic condition, SKOV3-sp cells were treated with ursolic acid $(3,10$, and $30 \mu \mathrm{g} / \mathrm{mL}), \mathrm{mRNAs}$ of ABCG2 and HIF-1 $\alpha$ were detected using quantitative PCR. ${ }^{*}<0.05$, ${ }^{* *} \mathrm{P}-\mathrm{values}$ represent that ursolic acid group is different compared with control group under hypoxia condition. (C) Immunofluorescence stain detected the expression of HIF-1 $\alpha$ in SKOV3-sp after treatment with ursolic acid for $48 \mathrm{~h}$ under hypoxic condition. (D) Immunofluorescence stain detected the expression of ABCG2 in SKOV3-sp after treatment with ursolic acid for $48 \mathrm{~h}$ under hypoxic condition. DAPI, 4',6-diamidino-2-phenylindole; GAPDH, glyceraldehyde 3-phosphate dehydrogenase; HIF, hypoxia-inducible factor; PCR, polymerase chain reaction.

$U A$ inhibits proliferation and reverses drug resistance of

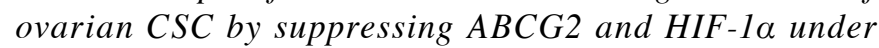
different culture conditions. In this experiment, it was observed that the ovarian CSCs were more drug resistant under hypoxic condition, and the expressions of ABCG2 and HIF-1 $\alpha$ were significantly increased simultaneously. The expression of ABCG2 has been proved to be closely associated with drug resistant cancer stem cells (35-38). Here, 3,10 , and $30 \mathrm{ml}\left(\mathrm{IC}_{10}, \mathrm{IC}_{25}\right.$, and $\left.\mathrm{IC}_{50}\right)$ were chosen to treat SKOV3-sp cells for $48 \mathrm{~h}$ to explore whether UA inhibit the expression of ABCG and HIF-1 $\alpha$. It was observed that under normal condition, different concentrations of UA could inhibit the stemness gene CD44, CD133, Nanog, and OCT-4 in a dose-dependent manner (Fig. 9A). Later, the mRNA of ABCG2 and HIF-1 $\alpha$ in SKOV3-sp treated with UA under hypoxic condition was tested. As shown in Fig. 9B, under hypoxic condition UA could suppress the expression of stemness genes CD44, CD133, Nanog, and Oct-4. High doses of UA could significantly inhibit ABCG 2 and HIF- $1 \alpha$. Immunofluorescence staining on SKOV3-sp under hypoxic condition was performed, and SKOV3-sp was treated with UA $(3,10$, and $30 \mu \mathrm{g} / \mathrm{ml}$ for $48 \mathrm{~h}$ ). In Fig. 9C and D, it shows an increase in the concentration of UA, the expression of HIF-1 $\alpha$ gradually reduced under hypoxic condition. The following conclusions were reached: UA could suppress the expression of ABCG2 and HIF-1 $\alpha$ under hypoxic conditions and in a dose-dependent manner.
HIF-1 $\alpha$ inhibitor YC-1 combined with UA suppressed the stemness gene and $A B C G 2$ under hypoxic condition. YC-1, which is 3-(5'-hydroxymethyl-2'-furyl)-1-benzyl-indazole, is a treatment for circulatory disorders, the inhibition of platelet aggregation, and vasoconstriction by inhibiting the soluble guanylate cyclase drugs. In 2001, Chun et al found that YC-1 inhibited the activity of HIF-1 (39) in breast cancer (40) and liver cancer (41), and was found to have the anti-tumor effect. To investigate whether inhibition of expression of HIF-1 $\alpha$ by YC-1 under hypoxic condition in SKOV3-sp cells is correlated with apoptosis, stemness, and drug-resistant gene ABCG2, the concentrations of YC-1 selected were 6, 14, and $32 \mu \mathrm{M}\left(\mathrm{IC}_{10}, \mathrm{IC}_{25}\right.$, and $\mathrm{IC}_{50}$ for $48 \mathrm{~h}$ ) was selected (Fig. 10A). It was found that with an increase in the concentration of YC-1, the expression of HIF-1 $\alpha$ was gradually reduced after treatment with YC-1 for $48 \mathrm{~h}$ under hypoxic condition (Fig. 10B). Later low-dose YC-1 $(6 \mu \mathrm{M})$ was used to treat SKOV3-sp for $48 \mathrm{~h}$. As shown in Fig. 10C, when low-dose YC-1 was used, the rate of apoptosis was $25.1 \%$, which was much higher than $7.9 \%$ under hypoxic condition.

When YC-1 was combined with UA under hypoxic condition, compared with YC-1 alone or UA, the stemness genes Nanog, OCT-4, CD44, and CD133 were significantly inhibited. In addition, the expression of ABCG2 was significantly decreased (Fig. 10D). These results suggest that after the inhibition of HIF-1 $\alpha$, the expression of ABCG2 was degraded.

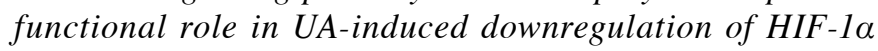


A

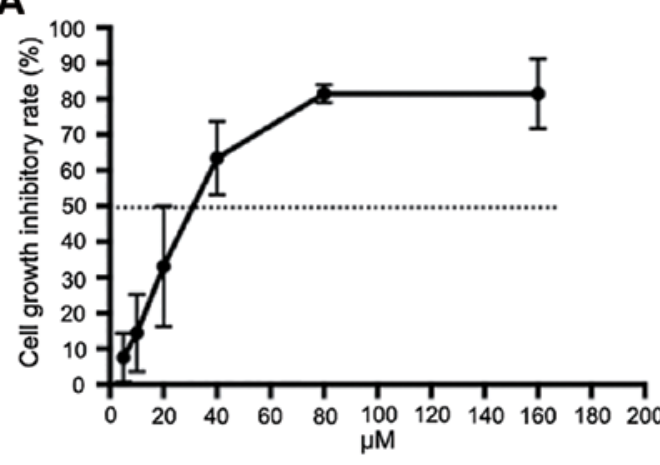

B

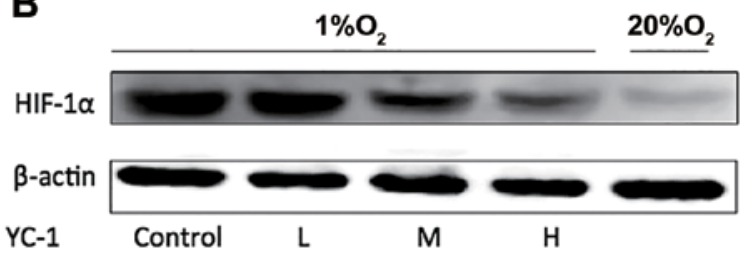

C
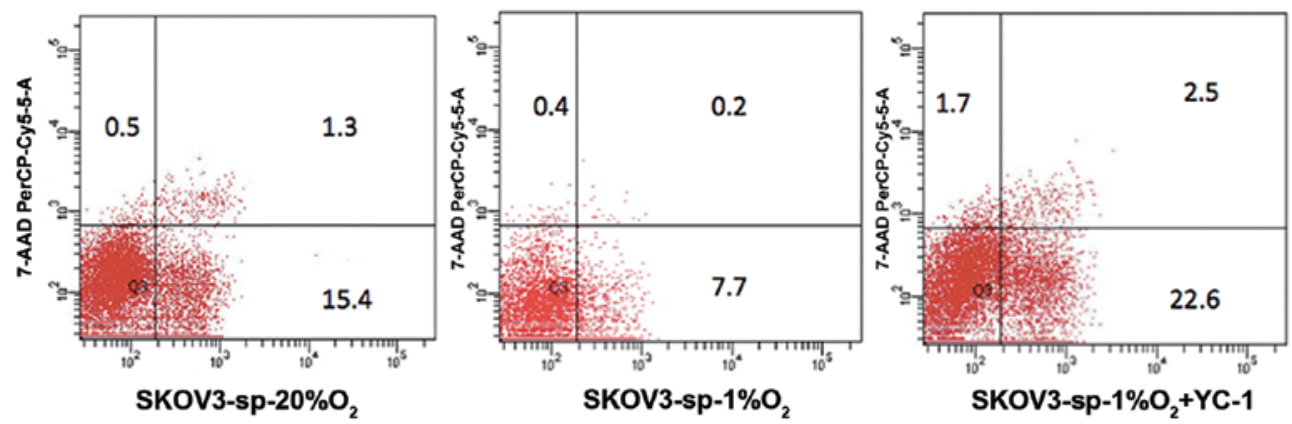

D

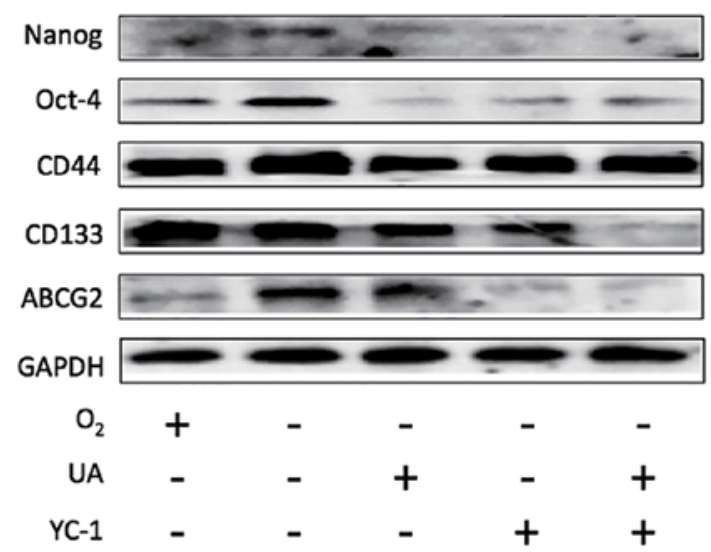

Figure 10. Inhibition of YC-1 on SKOV3-sp under hypoxic condition. (A) SKOV3-sp cells were treated with YC-1 (5, 10, 20, 40, 80 , and $160 \mu \mathrm{M})$ for $48 \mathrm{~h}$ under hypoxic condition. (B) Different concentrations of YC-1 $(6,14$, and $32 \mu \mathrm{M})$ were used to treat SKOV3-sp for $48 \mathrm{~h}$ to determine the inhibition on HIF-1 $\alpha$ under hypoxic condition. (C) The apoptosis of SKOV3-sp cells after treatment with low-dose YC-1 $(6 \mu \mathrm{M})$ under hypoxic condition. (D) The inhibition of YC-1 combined with ursolic acid on the stemness genes and ABCG2 under hypoxic condition. GAPDH, glyceraldehyde 3-phosphate dehydrogenase; HIF, hypoxia-inducible factor; UA, ursolic acid.

and reduction of $A B C G 2$. Emerging evidence suggests that $\mathrm{PI} 3 \mathrm{~K} / \mathrm{Akt}$ signaling mediates regulation and activation of HIF-1 $\alpha$ in various human cancers $(42,43)$. To investigate the relationship between HIF- $1 \alpha$ and ABCG2 and whether UA inhibited ABCG2 though downregulation of HIF-1 $\alpha$. The PI3K/Akt signaling pathway, small interfering RNA was used to knockdown the expression of HIF-1 $\alpha$. In this experiment, four sequences were chosen for design, synthesis, and confirmation by sequencing and cloned into pGPU6 vector. The transfection efficiency was detected using western blot and qPCR in SKOV3-ad under hypoxic condition. As shown in Fig. 11A, it can be observed that the positive control shRNA of GAPDH was suppressed obviously and the HIF-1 $\alpha$-Homo-764 site could inhibit the expression of HIF-1 $\alpha$ the level of RNA or protein levels. Next the HIF-1 $\alpha$-Homo-764 was chosen to transfect SKOV3-ad and after $48 \mathrm{~h}$ the ES medium was changed and the culture dish was treated with poly-HEMA to enrich sphere cells. The transfection efficiency was observed through the fluorescent microscope (Fig. 11B). Under hypoxic condition, no difference was observed between the control and shRNA of NC groups in the expression of HIF-1 $\alpha$, but in the shRNA of HIF-1 $\alpha$ of the expression of HIF-1 $\alpha$ showed a significant suppression (Fig. 11C). At the same time, the expression of ABCG2 also appeared to be inhibited (Fig. 11D).

To investigate whether the PI3K/Akt signaling was activated under hypoxic condition, the phosphorylation sites (p-Akt-492 and p-Akt-308) of the key protein Akt on the activation time of PI3K/Akt signaling pathway under hypoxic condition were detected. SKOV3-sp was used under hypoxic condition for $0,0.25,0.5,1,2,4,8$, and $24 \mathrm{~h}$ and then the expression of p-Akt was detected. It was observed that with the increase in hypoxia, the expression of p-Akt-492 and 
A

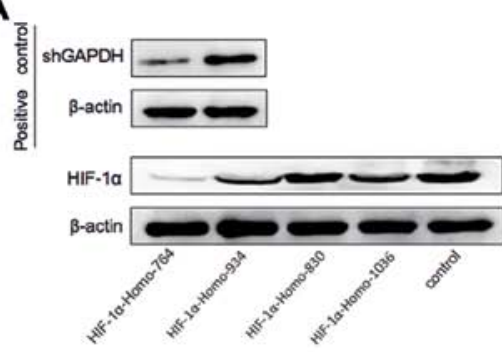

C
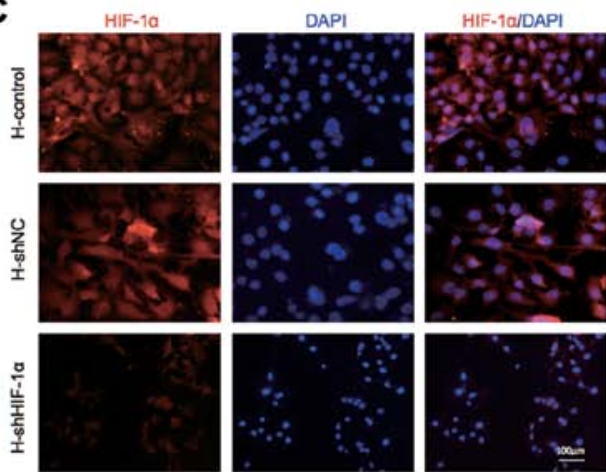

E

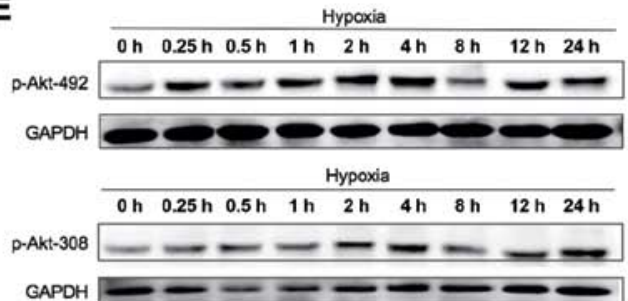

F

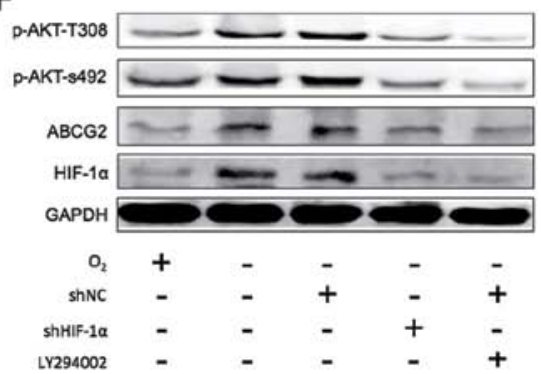

B
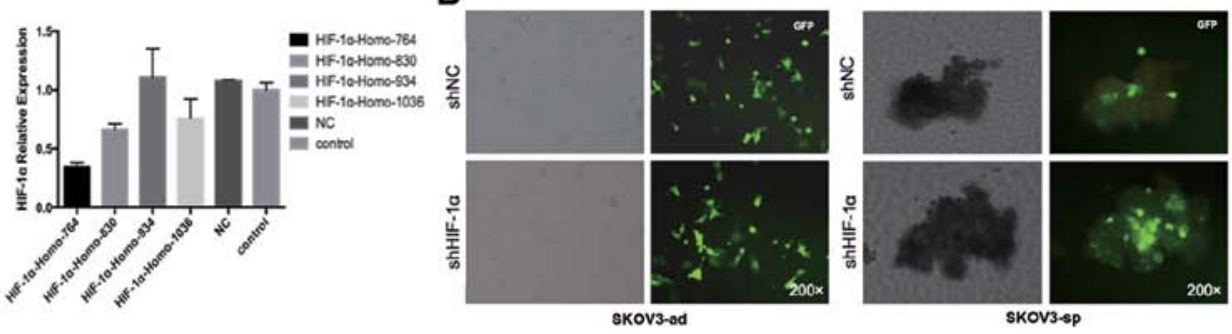

D
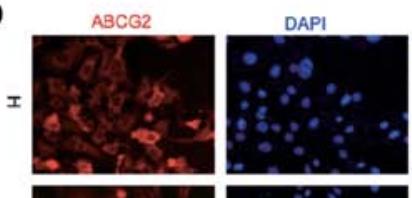

ABCG2/DAPI
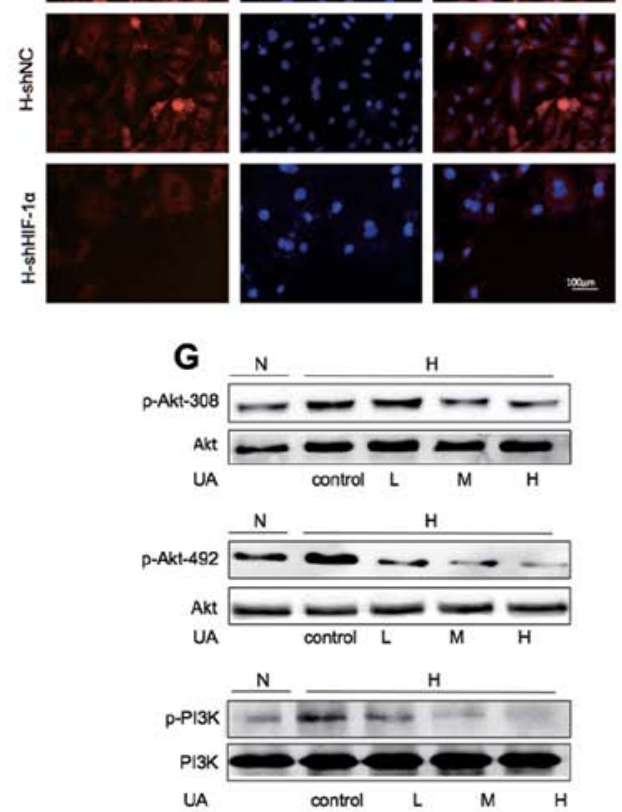

Figure 11. Ursolic acid inhibits ABCG2 though downregulation of HIF-1 $\alpha$. (A) The transfection efficiency was detected using western blot and quantitative PCR in the SKOV3-ad cells under hypoxic condition for $48 \mathrm{~h}$. (B) The transfection efficiency of HIF-1 $\alpha$-Homo-764 site in SKOV3-ad and SKOV3-sp under hypoxic condition for $48 \mathrm{~h}$ was detected using a fluorescent microscope. (C) After the knockdown of HIF-1 $\alpha$, the expression of HIF-1 $\alpha$ SKOV3-adin SKOV3-sp under hypoxic condition for $48 \mathrm{~h}$ was detected using fluorescent microscope. (D) After the knockdown of HIF-1, the expression of ABCG2 in SKOV3-sp under hypoxic condition for $48 \mathrm{~h}$ was detected using fluorescent microscope. (E) Western blot detected the activation time of phosphorylated Akt under different durations of hypoxia $(0,0.25,0.5,1,2,4,8,12$, and $24 \mathrm{~h})$. (F) Western blot detected the expression of p-Akt-492, p-Akt-308, HIF-1 $\alpha$, and ABCG2 in SKOV3-sp, which were treated with LY294002 or knockdown of HIF-1 $\alpha$ under hypoxic condition. (G) Western blot of the expression of p-Akt-492, p-Akt-308, and PI3K after SKOV3-sp was treated with UA (3, 10, and $30 \mu \mathrm{g} / \mathrm{mL})$. DAPI, 4',6-diamidino-2-phenylindole; GAPDH, glyceraldehyde 3-phosphate dehydrogenase; GFP, green fluorescent protein; HIF, hypoxia-inducible factor; PCr, polymerase chain reaction; UA, ursolic acid.

p-Akt-308 increased, reached a peak under hypoxic condition at $4 \mathrm{~h}$ and then declined (Fig. 11E). It was assessed that under hypoxic condition for $4 \mathrm{~h}$, AKT was activated. To elucidate whether the PI3K/Akt signaling pathway regulates the expression of ABCG2, HIF-1 $\alpha$ affects ABCG2, the PI3K inhibitor LY29004 $(44,45)$. Knockdown of HIF-1 $\alpha$ by shRNA were used to investigate HIF-1 $\alpha$ causing high expression of ABCG2 under hypoxic condition by the activation of the PI3K/Akt pathway. It was found that under hypoxic condition p-Akt-492, p-Akt-308, HIF-1 $\alpha$, and ABCG2 were significantly increased.
The knockdown of HIF-1 $\alpha$ and ABCG2 was inhibited, while p-Akt-492 and p-Akt-308 appeared reduced. Treatment with LY29004 resulted in a corresponding reduction in the expression of p-Akt-492 and p-Akt-308. In addition, the expression of phosphorylated Akt was reduced by the treatment with Ly29004, leading to further reduction in HIF-1 $\alpha$ and ABCG2 (Fig. 11F).

To investigate whether UA could inhibit the PI3K/Akt pathway, SKOV3-sp was treated with different concentrations of UA for $4 \mathrm{~h}$. A slight decrease in the expression of p-Akt-492 
and p-Akt-308 was noted, and the effect was more evident with increasing concentrations, while the expression of PI3K gradually decreased (Fig. 11G). It can be concluded that UA inhibits the activation under hypoxic conditions in the PI3K/ Akt signaling pathway.

\section{Discussion}

Ovarian cancer is the most lethal among the gynecologic malignancies as it is diagnosed at an advanced stage in most patients. In spite of success in initial treatment with a combination of surgical debulking and chemotherapy, unacceptably large number of patients (70\%) develop terminal, recurrent, chemotherapeutic resistance (46). With the development of CSC theory and assays using markers for the enrichment of CSCs, functional assays have been used to demonstrate CSCs in ovarian cancer. Studies have shown that the CSCs can be identified in tumors by their ability to grow in spheres, which are known as tumor spheres. CSCs from epithelial organs can be expanded as sphere-like cellular aggregates in a serum-free medium containing epidermal growth factor and bFGF (47-50). In these spheres, $4-20 \%$ of the cells are stem cells; the others are progenitor cells in various phases of differentiation, which enrich the CSC population by sphere formation and it is applicable to ovarian CSCs (51-53). In this study, the serum-free suspension culture was chosen to enrich the ovarian CSCs. A small population of tumorigenic cells from the ovarian cancer cell lines SKOV3, A2780, and HEY was chosen. Among these sphere cells, it can be observed that the stem cell markers CD44, CD133, Nanog, and OCT-4 were expressed more than the normal cells, and ABCG2, which is widely expressed in various stem cell populations, is highly expressed in sphere cells and is responsible for the maintenance of sphere phenotype (5). As a key MDR transporter, ABCG2 has the capability to efflux various chemotherapeutic drugs and may contribute to drug resistance of cancer cells (54). At the same time, ABCG2, as one of the important stem cell markers, has close association with CSCs. The expression of ABCG2 in stem cells from tumor tissues and tumor cells indicates its important role in stem cell biology. In the present study, the expression of ABCG2 in the SKOV3-sp, A2780-sp, and HEY-sp was found to increase significantly. The ovarian cancer sphere cells increased the cisplatin resistance as compared with the adherent cells.

Hypoxia-induced drug resistance has been observed in vitro in breast carcinoma neuroblastoma, and colon cancer (55-57). HIF-1 $\alpha$ mediates the cellular response to hypoxia and the master regulators of stem properties $(58,59)$. In the present study, the increase in HIF- $1 \alpha$, and the change in the stemness of ovarian CSCs and the ABCG2 were tested under hypoxic condition. It was found that under hypoxic condition for $48 \mathrm{~h}$ in the spheres of SKOV3, A2780, and HEY, in addition to increased HIF, stem genes CD44, CD133, Nanog, Oct-4, and $\mathrm{ABCG} 2$ have experienced different degrees of increase. The sphere cells elevated the resistance to cisplatin. Here the following inference was obtained: under hypoxic condition, hypoxia induces drug resistance due to increased HIF-1 $\alpha$ and elevated ABCG2.

UA is one of the active compounds in Chinese anticancer herbal medicine. In the present study, it was found that low doses of UA (which was found to be no different from untreated cells and recognized as non-cytotoxic dose) in combination with cisplatin could induce apoptosis significantly as compared to cisplatin alone. Moreover, UA in combination with cisplatin significantly enhanced the cytotoxicity of cisplatin to suppress ovarian CSCs. It could be considered that UA increases the sensitivity of cisplatin under hypoxic condition. Therefore, in the succeeding experiments, the reversal of resistance mechanisms of UA under hypoxic conditions was explored.

In this study, it was found that under hypoxic condition, UA inhibited the expression of HIF-1 $\alpha$ and can simultaneously inhibit the expression of resistance gene ABCG2; with the increase in the concentration of the inhibition increasing more obviously. Therefore, it is suspected that UA decreases the expression of HIF-1 $\alpha$ to inhibit ABCG2 to reverse the resistance of ovarian CSCs. In this experiment, to elucidate whether the expression of ABCG2 is correlated with the expression of HIF-1 $\alpha$, the HIF-1 $\alpha$ inhibitor YC-1 was chosen to treat the SKOV3 sphere cells. It was found that with an increase in the concentration of $\mathrm{YC}-1$, the expression of HIF-1I gradually decreased. Later, the low-dose YC-1 was chosen to treat SKOV3 sphere cells under hypoxic conditions; the rate of apoptosis increased significantly. After treatment with low concentrations of YC-1. At the same time, it was found that after treatment with YC-1, the increasing ABCG2 under hypoxia condition appeared suppressed. When UA was combined with YC-1, the expression of ABCG2 showed a significant decrease.

Under hypoxic condition, enhanced expression of HIF-1 $\alpha$ in high tumorigenic cancer stem/progenitor cells sustained the activation PI3K/Akt $(60,61)$. A recent study suggests that the PI3K/Akt signaling mediates the regulation and activation of HIF-1 $\alpha(43,45)$. Moreover, excessive activation of PI3K/Akt plays an important role in the chemotherapeutic resistance $(62,63)$. However, whether the PI3K/Akt signaling pathway, which is activated by hypoxia, effects resistance through the regulation of the resistant gene ABCG2 is not clear. Whether the mechanism is impacted by HIF-1 $\alpha$ is worth exploring. Hence in the present study, the activation time of p-Akt in SKOV3-sp was tested under hypoxic condition. As a result, it was found that with an increase in hypoxia, the expression of p-Akt-492 and p-Akt-308 was increased, and reached a peak under hypoxia for $4 \mathrm{~h}$ and then declined. Later HIF-1 $\alpha$ was knocked down by shRNA and the PI3K inhibitor LY294002 was chosen. It was found that inhibiting the PI3K/Akt activity by the inhibitor LY294002 decreased the expression of HIF-1 $\alpha$ in A2780-sp cells. Knockdown of HIF-1 $\alpha$, to some extent, can inhibit the expression of phosphorylated Akt. In the succeeding experiment, it was found that when SKOV3-sp is treated with UA under hypoxia it can significantly inhibit the expression of the key protein phosphorylated PI3K and phosphorylated Akt on the PI3K/Akt signaling pathway. The result indicated that under hypoxic condition UA could inhibit the PI3K/Akt signaling pathway activated by the hypoxic condition.

In summary, it was demonstrated that under hypoxic condition UA could inhibit the proliferation and reversal of drug-resistant ovarian CSCs by suppressing the expression of downregulation of HIF-1 $\alpha$ and ABCG2. PI3K/Akt signaling 
pathway activation plays an important functional role in UA-induced downregulation of HIF- $1 \alpha$ and ABCG2 reduction. This study indicates that UA, a compound in traditional Chinese medicine, is a promising agent to reverse drugresistance in ovarian CSCs.

\section{Acknowledgements}

This study was supported by the National Natural Science Foundation of China (nos. 81173291, 81303106, 81573805) and the Program of Science and Technology Commission of Shanghai Municipality (no. 13ZR1462200).

\section{References}

1. Jemal A, Siegel R, Xu J and Ward E: Cancer statistics, 2010. CA Cancer J Clin 60: 277-300, 2010.

2. Siegel R, Naishadham D and Jemal A: Cancer statistics, 2012. CA Cancer J Clin 62: 10-29, 2012.

3. Kitamura H, Okudela K, Yazawa T, Sato H and Shimoyamada H: Cancer stem cell: Implications in cancer biology and therapy with special reference to lung cancer. Lung Cancer 66: 275-281, 2009.

4. Szotek PP, Pieretti-Vanmarcke R, Masiakos PT, Dinulescu DM, Connolly D, Foster R, Dombkowski D, Preffer F, Maclaughlin DT and Donahoe PK: Ovarian cancer side population defines cells with stem cell-like characteristics and Mullerian Inhibiting Substance responsiveness. Proc Natl Acad Sci USA 103: 11154-11159, 2006.

5. Zhou S, Schuetz JD, Bunting KD, Colapietro AM, Sampath J, Morris JJ, Lagutina I, Grosveld GC, Osawa M, Nakauchi H, et al: The ABC transporter Bcrp1/ABCG2 is expressed in a wide variety of stem cells and is a molecular determinant of the sidepopulation phenotype. Nat Med 7: 1028-1034, 2001.

6. Zhang G, Wang Z, Luo W, Jiao H, Wu J and Jiang C: Expression of potential cancer stem cell marker ABCG2 is associated with malignant behaviors of hepatocellular carcinoma. Gastroenterol Res Pract 2013: 782581, 2013.

7. Natarajan K, Xie Y, Baer MR and Ross DD: Role of breast cancer resistance protein (BCRP/ABCG2) in cancer drug resistance. Biochem Pharmacol 83: 1084-1103, 2012.

8. Noguchi K, Katayama K and Sugimoto Y: Human ABC transporter ABCG2/BCRP expression in chemoresistance: Basic and clinical perspectives for molecular cancer therapeutics. Pharm Genomics Pers Med 7: 53-64, 2014.

9. Wu CP, Sim HM, Huang YH,Liu YC,Hsiao SH, Cheng HW,Li YQ, Ambudkar SV and Hsu SC: Overexpression of ATP-binding cassette transporter ABCG2 as a potential mechanism of acquired resistance to vemurafenib in $\mathrm{BRAF}(\mathrm{V} 600 \mathrm{E})$ mutant cancer cells. Biochem Pharmacol 85: 325-334, 2013.

10. Nakanishi T and Ross DD: Breast cancer resistance protein (BCRP/ABCG2): Its role in multidrug resistance and regulation of its gene expression. Chin J Cancer 31: 73-99, 2012.

11. Semenza GL: Defining the role of hypoxia-inducible factor 1 in cancer biology and therapeutics. Oncogene 29: 625-634, 2010.

12. Oda K, Nishimura T, Higuchi K, Ishido N, Ochi $K$, Iizasa $H$, Sai Y, Tomi M and Nakashima E: Estrogen receptor $\alpha$ induction by mitoxantrone increases Abcg2 expression in placental trophoblast cells. J Pharm Sci 102: 3364-3372, 2013.

13. Chen S, Zhang M, Xing L, Wang Y, Xiao Y and Wu Y: HIF-1 $\alpha$ contributes to proliferation and invasiveness of neuroblastoma cells via SHH signaling. PLoS One 10: e0121115, 2015.

14. Wan J, Chai H, Yu Z, Ge W, Kang N, Xia W and Che Y: HIF-1 $\alpha$ effects on angiogenic potential in human small cell lung carcinoma. J Exp Clin Cancer Res 30: 77, 2011.

15. Thomas R and Kim MH: HIF-1 alpha: A key survival factor for serum-deprived prostate cancer cells. Prostate 68: 1405-1415, 2008.

16. Liu J: Pharmacology of oleanolic acid and ursolic acid. J Ethnopharmacol 49: 57-68, 1995.

17. Tang X, Yan L, Xu L and Gao J: Comparative study on the hepatoprotective and anti-oxidation effects of oleanolic acid, ursolic acid and asiatic acid. Lishizhen Med Materia Med Res 21: 2824-2827, 2012. http://en.cnki.com.cn/Article_en/ CJFDTOTAL-SZGY201011046.htm.
18. Ikeda Y, Murakami A and Ohigashi H: Ursolic acid: An anti- and pro-inflammatory triterpenoid. Mol Nutr Food Res 52: 26-42, 2008.

19. Martin-Aragón S, de las Heras B, Sanchez-Reus MI and Benedi J: Pharmacological modification of endogenous antioxidant enzymes by ursolic acid on tetrachloride-induced liver damage in rats and primary cultures of rat hepatocytes. Exp Toxicol Pathol 53: 199-206, 2001.

20. Zhang J, Wang W, Qian L, Zhang Q, Lai D and Qi C: Ursolic acid inhibits the proliferation of human ovarian cancer stem-like cells through epithelial-mesenchymal transition. Oncol Rep 34: 2375-2384, 2015 .

21. Lim JJ, Yang K, Taylor-Harding B, Wiedemeyer WR and Buckanovich RJ: VEGFR3 inhibition chemosensitizes ovarian cancer stemlike cells through down-regulation of BRCA1 and BRCA2. Neoplasia 16: 343-353, 2014.

22. Huang R, Wang J, Zhong Y, Liu Y, Stokke T, Trope CG, Nesland JM and Suo Z: Mitochondrial DNA deficiency in ovarian cancer cells and cancer stem cell-like properties. Anticancer Res 35: 3743-3753, 2015.

23. Ruiz I, Martín-Arruti M, Lopez-Lopez E and Garcia-Orad A: Lack of association between deficient mismatch repair expression and outcome in endometrial carcinomas of the endometrioid type. Gynecol Oncol 134: 20-23, 2014.

24. Hiraga $T$, Ito $S$ and Nakamura $H$ : Side population in MDA-MB-231 human breast cancer cells exhibits cancer stem cell-like properties without higher bone-metastatic potential. Oncol Rep 25: 289-296, 2011.

25. Kim RJ and Nam JS: OCT4 expression enhances features of cancer stem cells in a mouse model of breast cancer. Lab Anim Res 27: 147-152, 2011.

26. Gazda LS, Martis PC, Laramore MA, Bautista MA, Dudley A, Vinerean HV and Smith BH: Treatment of agarose-agarose RENCA macrobeads with docetaxel selects for OCT4(+) cells with tumor-initiating capability. Cancer Biol Ther 14: 1147-1157, 2013.

27. Silva IA, Bai S, McLean K, Yang K, Griffith K, Thomas D, Ginestier C, Johnston C, Kueck A, Reynolds RK, et al: Aldehyde dehydrogenase in combination with CD133 defines angiogenic ovarian cancer stem cells that portend poor patient survival. Cancer Res 71: 3991-4001, 2011.

28. Nam EJ, Lee M, Yim GW, Kim JH, Kim S, Kim SW and Kim YT: MicroRNA profiling of a CD133(+) spheroid-forming subpopulation of the OVCAR3 human ovarian cancer cell line. BMC Med Genomics 5: 18, 2012.

29. Casagrande F, Cocco E, Bellone S, Richter CE, Bellone M, Todeschini P, Siegel E, Varughese J, Arin-Silasi D, Azodi M, et al: Eradication of chemotherapy-resistant $\mathrm{CD} 44^{+}$human ovarian cancer stem cells in mice by intraperitoneal administration of Clostridium perfringens enterotoxin. Cancer 117: 5519-5528, 2011.

30. Chiou SH, Wang ML, Chou YT, Chen CJ, Hong CF, Hsieh WJ, Chang HT, Chen YS, Lin TW, Hsu HS, et al: Coexpression of Oct4 and Nanog enhances malignancy in lung adenocarcinoma by inducing cancer stem cell-like properties and epithelialmesenchymal transdifferentiation. Cancer Res 70: 10433-10444, 2010.

31. Wenger RH: Cellular adaptation to hypoxia: $\mathrm{O}_{2}$-sensing protein hydroxylases, hypoxia-inducible transcription factors, and $\mathrm{O}_{2}$-regulated gene expression. FASEB J 16: 1151-1162, 2002.

32. Mathieu J, Zhang Z, Zhou W, Wang AJ, Heddleston JM, Pinna CM, Hubaud A, Stadler B, Choi M, Bar M, et al: HIF induces human embryonic stem cell markers in cancer cells. Cancer Res 71: 4640-4652, 2011.

33. Jubb AM, Buffa FM and Harris AL: Assessment of tumour hypoxia for prediction of response to therapy and cancer prognosis. J Cell Mol Med 14: 18-29, 2010.

34. Milosevic M, Warde P, Ménard C, Chung P, Toi A, Ishkanian A, McLean M, Pintilie M, Sykes J, Gospodarowicz M, et al: Tumor hypoxia predicts biochemical failure following radiotherapy for clinically localized prostate cancer. Clin Cancer Res 18: 2108-2114, 2012.

35. Yang Y, Fan Y, Qi Y, Liu D, Wu K, Wen F and Zhao S: Side population cells separated from A549 lung cancer cell line possess cancer stem cell-like properties and inhibition of autophagy potentiates the cytotoxic effect of cisplatin. Oncol Rep 34: 929-935, 2015. 
36. Xie ZY, Lv K, Xiong Y and Guo WH: ABCG2-meditated multidrug resistance and tumor-initiating capacity of side population cells from colon cancer. Oncol Res Treat 37: 666-668, 2014.

37. Warrier S, Pavanram P, Raina D and Arvind M: Study of chemoresistant CD133+ cancer stem cells from human glioblastoma cel line U138MG using multiple assays. Cell Biol Int 36: 1137-1143, 2012.

38. Oh PS, Patel VB, Sanders MA, Kanwar SS, Yu Y, Nautiyal J, Patel BB and Majumdar AP: Schlafen-3 decreases cancer stem cell marker expression and autocrine/juxtacrine signaling in FOLFOX-resistant colon cancer cells. Am J Physiol Gastrointest Liver Physiol 301: G347-G355, 2011.

39. Chun YS, Yeo EJ, Choi E, Teng CM, Bae JM, Kim MS and Park JW: Inhibitory effect of YC-1 on the hypoxic induction of erythropoietin and vascular endothelial growth factor in Hep3B cells. Biochem Pharmacol 61: 947-954, 2001.

40. Cheng Y, Li W, Liu Y, Cheng HC, Ma J and Qiu L: YC-1 exerts inhibitory effects on MDA-MB-468 breast cancer cells by targeting EGFR in vitro and in vivo under normoxic condition. Chin J Cancer 31: 248-256, 2012.

41. Kong J, Kong F, Gao J, Zhang Q, Dong S, Gu F, Ke S, Pan B, Shen Q, Sun H, et al: YC-1 enhances the anti-tumor activity of sorafenib through inhibition of signal transducer and activator of transcription 3 (STAT3) in hepatocellular carcinoma. Mol Cancer 13: 7, 2014.

42. Zhong H, Chiles K, Feldser D, Laughner E, Hanrahan C, Georgescu MM, Simons JW and Semenza GL: Modulation of hypoxia-inducible factor 1alpha expression by the epidermal grow th factor/phosphatidylinositol 3-kinase/PTEN/AKT/FRAP pathway in human prostate cancer cells: Implications for tumor angiogenesis and therapeutics. Cancer Res 60: 1541-1545, 2000.

43. Mazure NM, Chen EY, Laderoute KR and Giaccia AJ: Induction of vascular endothelial growth factor by hypoxia is modulated by a phosphatidylinositol 3-kinase/Akt signaling pathway in Ha-ras-transformed cells through a hypoxia inducible factor-1 transcriptional element. Blood 90: 3322-3331, 1997.

44. Bleau AM, Hambardzumyan D, Ozawa T, Fomchenko EI, Huse JT, Brennan CW and Holland EC: PTEN/PI3K/Akt pathway regulates the side population phenotype and ABCG2 activity in glioma tumor stem-like cells. Cell Stem Cell 4: 226-235, 2009.

45. Kilic-Eren M, Boylu T and Tabor V: Targeting PI3K/Akt represses Hypoxia inducible factor- $1 \alpha$ activation and sensitizes Rhabdomyosarcoma and Ewing's sarcoma cells for apoptosis. Cancer Cell Int 13: 36, 2013

46. Lengyel E: Ovarian cancer development and metastasis. Am J Pathol 177: 1053-1064, 2010.

47. Dontu G, Abdallah WM, Foley JM, Jackson KW, Clarke MF, Kawamura MJ and Wicha MS: In vitro propagation and transcriptional profiling of human mammary stem/progenitor cells. Genes Dev 17: 1253-1270, 2003.

48. Uchida N, Buck DW, He D, Reitsma MJ, Masek M, Phan TV, Tsukamoto AS, Gage FH and Weissman IL: Direct isolation of human central nervous system stem cells. Proc Natl Acad Sci USA 97: 14720-14725, 2000.

49. Lee J, Kotliarova S, Kotliarov Y, Li A, Su Q, Donin NM, Pastorino S, Purow BW, Christopher N, Zhang W, et al: Tumor stem cells derived from glioblastomas cultured in bFGF and EGF more closely mirror the phenotype and genotype of primary tumors than do serum-cultured cell lines. Cancer Cell 9: 391-403, 2006.
50. Kim CF, Jackson EL, Woolfenden AE, Lawrence S, Babar I, Vogel S, Crowley D, Bronson RT and Jacks T: Identification of bronchioalveolar stem cells in normal lung and lung cancer. Cell 121: 823-835, 2005.

51. Reynolds BA and Weiss S: Clonal and population analyses demonstrate that an EGF-responsive mammalian embryonic CNS precursor is a stem cell. Dev Biol 175: 1-13, 1996.

52. Wang L, Mezencev R, Bowen NJ, Matyunina LV and McDonald JF: Isolation and characterization of stem-like cells from a human ovarian cancer cell line. Mol Cell Biochem 363: 257-268, 2012.

53. Soriţău O, Tomuleasa CI, Páll E, Virág P, Fischer-Fodor E, Foris V, Barbos O, Tatomir C, Kacsó G and Irimie A: Enhanced chemoresistance and tumor sphere formation as a laboratory model for peritoneal micrometastasis in epithelial ovarian cancer. Rom J Morphol Embryol 51: 259-264, 2010.

54. Frelet $A$ and Klein M: Insight in eukaryotic ABC transporter function by mutation analysis. FEBS Lett 580: 1064-1084, 2006.

55. Adamski J, Price A, Dive C and Makin G: Hypoxia-induced cytotoxic drug resistance in osteosarcoma is independent of HIF-1Alpha. PLoS One 8: e65304, 2013.

56. Xiang L, Liu ZH, Huan Q, Su P, Du GJ, Wang Y, Gao P and Zhou GY: Hypoxia-inducible factor-2a is associated with ABCG2 expression, histology-grade and Ki67 expression in breast invasive ductal carcinoma. Diagn Pathol 7: 32, 2012.

57. Chen J, Ding Z, Peng Y, Pan F, Li J, Zou L, Zhang Y and Liang H: HIF-1 $\alpha$ inhibition reverses multidrug resistance in colon cancer cells via downregulation of MDR1/P-glycoprotein. PLoS One 9: e98882, 2014.

58. Méndez O, Zavadil J, Esencay M, Lukyanov Y, Santovasi D, Wang SC, Newcomb EW and Zagzag D: Knock down of HIF-1alpha in glioma cells reduces migration in vitro and invasion in vivo and impairs their ability to form tumor spheres. Mol Cancer 9: 133, 2010.

59. Yang L, Lin C, Wang L, Guo $\mathrm{H}$ and Wang X: Hypoxia and hypoxia-inducible factors in glioblastoma multiforme progression and therapeutic implications. Exp Cell Res 318: 2417-2426, 2012.

60. Manohar SM, Padgaonkar AA, Jalota-Badhwar A, Sonawane V, Rathos MJ, Kumar S and Joshi KS: A novel inhibitor of hypoxiainducible factor-1 $\alpha$ P3155 also modulates PI3K pathway and inhibits growth of prostate cancer cells. BMC Cancer 11: 338, 2011.

61. Befani CD, Vlachostergios PJ, Hatzidaki E, Patrikidou A, Bonanou S, Simos G, Papandreou CN and Liakos P: Bortezomib represses HIF-1 $\alpha$ protein expression and nuclear accumulation by inhibiting both PI3K/Akt/TOR and MAPK pathways in prostate cancer cells. J Mol Med Berl 90: 45-54, 2012.

62. Chen Y, Wang BC and Xiao Y: PI3K: A potential therapeutic target for cancer. J Cell Physiol 227: 2818-2821, 2012.

63. Fulda S: The PI3K/Akt/mTOR pathway as therapeutic target in neuroblastoma. Curr Cancer Drug Targets 9: 729-737, 2009. 